\title{
More whale strandings are linked to sonar
}

Examinations of four whales found stranded along the Spanishcoast in January seem to confirm a 2003 Nature report linking sonar to the deaths of several beaked whales. In recentyears, naval sonar devices have been the suspected cause of an increasing number of whale strandings worldwide. The whales are thought to take evasive action to avoid the noise, sometimes diving and surfacing until they suffer decompression sickness and die. In 2003, British and Spanish researchers reported that Cuvier's beaked whales (Ziphius cavirostris), stranded off the Canary Islands the previous year, had deadly gas-bubble lesions called emboli in their livers. They suggested these were caused by decompression (P. D. Jepson etal.

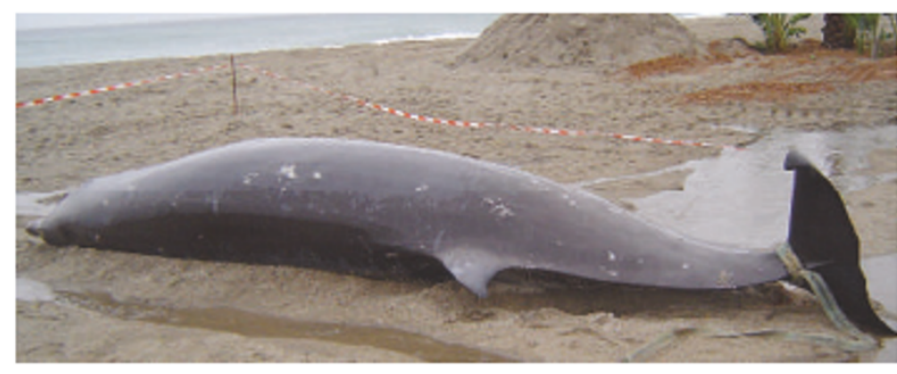

Air bubbles have been found in the tissues of dead whales discoveredin Spain.

Nature 425, 575-576; 2003).

After a group of beaked whales went ashore in January, along Spain's Costa del Sol, the Spanish Cetacean Society in Madrid called veterinarian Antonio Fernandez to perform necropsies on four of the animals. He and his colleagues from the University of Las Palmas de Gran Can aria found the same embolic syndrome as that found in the 2003 study.

"This is the first confirmation of the 2003 report," says veterinarian Paul Jepson of the Zoological Society of London, lead author of that article. The new findings are expected to be published in comingmonths.

Officials at the Cetacean Society suspect that mid-frequency naval sonar caused the strandings. But Fernandez notes that the ships that might have been responsible have not been identified.

Earlier this month, about 45 pilot whales died after stranding on the westernside of the island of Sulawesi in Indonesia, following joint US and Indonesian naval exercises in the nearby Macassar Strait. The cause of the stranding is under investigation.

Some US Navy officials, and oceanographers who use devices to generate air bur sts underwater for seismic studies, have been accused of blocking efforts to uncover the links between noise and whale strandings (see Nature 439, 376-377; 2006).

Rex Dalton 